\title{
Parasites of native Cichlidae populations and invasive Oreochromis niloticus (Linnaeus, 1758) in tributary of Amazonas River (Brazil)
}

\author{
Parasitos de populaçôes de Cichlidae nativos e invasora Oreochromis niloticus (Linnaeus, 1758) \\ em tributário do Rio Amazonas (Brasil) \\ Luana Silva Bittencourt'; Douglas Anadias Pinheiro²; Melissa Querido Cárdenas ${ }^{3}$; \\ Berenice Maria Fernandes ${ }^{3}$; Marcos Tavares-Dias ${ }^{1,2 *}$
}

\begin{abstract}
${ }^{1}$ Programa de Pós-graduação em Biodiversidade Tropical - PPGBio, Universidade Federal do Amapá - UNIFAP, Macapá, AP Brazil ${ }^{2}$ Laboratório de Aquicultura e Pesca, Embrapa Amapá, Macapá, AP, Brazil

${ }^{3}$ Laboratório de Helmintos Parasitos de Peixes, Instituto Oswaldo Cruz, Fundação Oswaldo Cruz -Fiocruz, Rio de Janeiro, RJ, Brasil
\end{abstract}

Received August 21, 2013

Accepted December 16, 2013

\begin{abstract}
This study provides the first investigation on acquisition of parasites in invasive $O$. niloticus by parasite species of native Cichlidae from the Igarapé Fortaleza basin, Northern Brazil. There were examined 576 specimens of 16 species of native cichlids and invasive O. niloticus collected in the main channel and the floodplain area of this tributary of Amazon River. The invasive O. niloticus was poorly parasitized having only Ichthyophthirius multifliis, Trichodina centrostrigeata, Paratrichodina africana, Trichodina nobilis (Protozoa) and Cichlidogyrus tilapiae (Monogenoidea), and this host has not acquired any parasite species common to the native ichthyofauna region. In contrast, species of native cichlids showed rich fauna of parasites with predominance of Monogenoidea species, larvae and adults of Nematoda, Digenea, Cestoidea and Acanthocephala, besides four species of Protozoa and four Crustacea. However, only T. nobilis was acquired by native fish, the Aequidens tetramerus, which is a new host for this exotic Trichodinidae. In $O$. niloticus, well established in the region, the small number of helminth species may be associated with its rusticity, good adaptation in the new environment and also the presence of native parasites with relative specificity, but without ability to complete its life cycle in this invasive host of this ecosystem.
\end{abstract}

Keywords: Colonization, biological invasion, fish parasites.

\section{Resumo}

Este estudo é a primeira investigação da aquisição de parasitos na invasora $O$. niloticus por espécies de parasitos Cichlidae nativos da bacia Igarapé Fortaleza, Norte do Brasil. Foram examinados 576 espécimes pertencentes a 16 espécies de ciclídeos nativos e à invasora $O$. niloticus coletados no canal principal e área da planície de inundação deste tributário do Rio Amazonas. A invasora O. niloticus foi pobremente parasitada, pois teve somente Ichthyophthirius multifiliis, Trichodina centrostrigeata, Paratrichodina africana e Trichodina nobilis (Protozoa) e Cichlidogyrus tilapiae (Monogenoidea) e náo adquiriu qualquer espécie comum à ictiofauna nativa da regiáo. Em contraste, as espécies de ciclídeos nativos apresentaram uma rica fauna de parasitos com predominância de espécies de helmintos Monogenoidea, larvas e adultos de Nematoda, Digenea, Cestoidea e Acanthocephala, além de quatro espécies de Protozoa e quatro Crustacea. Porém, somente T. nobilis foi encontrado em peixe nativo, Aequidens tetramerus, que é um novo hospedeiro para esse Trichodinidae exótico. Em O. niloticus, já bem estabelecida na região, o reduzido número de espécies de helmintos pode estar associado à sua rusticidade, boa adaptação ao novo ambiente e também à presença de parasitos nativos com relativa especificidade, mas sem habilidade em completar seu ciclo de vida nesse hospedeiro invasor desse ecossistema.

Palavras-chave: Colonização, invasão biológica, parasitos de peixes.

\footnotetext{
${ }^{*}$ Corresponding author: Marcos Tavares Dias

Embrapa Amapá, Rod. Juscelino Kubitschek, Km 5, 2600,

CEP 68903-419, Macapá, AP, Brasil

e-mail: marcos.tavares@embrapa.br; mtavaresdias@pq.cnpq.br
} 


\section{Introduction}

Biological invasions are occurring worldwide at alarming rates being widely recognized as threats to the integrity and functioning of natural ecosystems (GALLI et al., 2007; POULIN et al., 2011). Whenever a species in a given region is moved to another one, there is always the possibility that its parasites can be taken with it (MENDOZA-FRANCO et al., 2006; GALLI et al., 2007) forming a biotic unit called symbiota by Galli et al. (2005).

In Brazil, despite the introduction of Oreochromis niloticus for culture purposes for over 40 years, some studies on this exotic fish fauna in the natural environment were performed (RANZANIPAIVA et al., 2005), but studies on the transmission of parasites to native ichthyofauna are still scarce (GRAÇA; MACHADO, 2007). However, when a non-native fish is introduced, the exchange of parasites between native and non-native hosts can be expected depending on many factors related to the host-parasite system.

In a new habitat, the establishment success of an exotic parasite species depends on the acceptable abiotic conditions and complexity of the parasites' life cycle (GALLI et al., 2005; RIBEIRO; LEUNDA, 2012). The transmission of exotic parasites depends, primarily, on biological factors, host-parasite interaction, congeniality of host species and parasite specificity (JIMÉNEZGARCÍA et al., 2001; GALLI et al., 2005; ROCHE et al., 2010; RIBEIRO; LEUNDA, 2012). Thus, the intensity and type of native parasites (ectoparasites and endoparasites) acquired vary among different invasive exotic hosts (PATERSON et al., 2012).

The consequences of acquiring new parasites are also difficult to predict, but severe illness may occur in native fish at the beginning, because they do not share a co-evolutionary history with new parasites (ROCHE et al., 2010; GENDRON et al., 2012) and may even suffer a dynamics change of their relationship with their native parasites (PATERSON et al., 2012). Invasive fish may lose parasites from their place of origin during translocation and, then its parasitic fauna may be dominated by native species of parasites common to the local ichthyofauna (ROCHE et al., 2010; PATERSON et al., 2012). In this case, they may represent a very important role in the life cycle of species of endohelminthic parasites (POULIN et al., 2011) depending on lifestyle and diet of invasive fish. The omnivorous feeding habit of $O$. niloticus favors the occurrence of endohelminthic species and indicates this fish as part of intermediate levels in the food web (GRAÇA; MACHADO, 2007). Regarding fish, one of the factors influencing the composition of parasites fauna is its origin in the area, that is, whether it is a native or exotic host.

The biological invasions can still cause a sudden increase in the incidence or severity diseases in previously existing native host, due to the pressure on these populations (GALLI et al., 2007; POULIN et al., 2011; GENDRON et al., 2012), when they change their behavior or their immunocompetence. However, when these impacts cause the extinction of essential hosts in the life cycle of a native parasite, the population of this area will decline considerably, thus, benefiting other native hosts of this parasite (POULIN et al., 2011). Nonetheless, these negative impacts on native populations are only detected late, due to the difficulty of quick perception of the transition of exotic parasites in the natural aquatic environment. Therefore, since future consequences of invasion of exotic parasites are difficult to estimate (ROCHE et al., 2010), it is necessary to monitor the establishment of exotic parasites in order to identify species translocated from its area of origin and transmitted to local ichthyofauna. By doing this, it will be possible to understand and predict potential impacts caused to native ichthyofauna in invaded natural ecosystem.

In the State of Amapá, Northern Brazil, 18 years after the introduction of $O$. niloticus in several fish farms there were invasion and establishment of this fish in the Igarapé Fortaleza basin, an important tributary of the Amazon River. This invasion is causing strong pressure on the biomass of Cichlidae species of the local ichthyofauna, due to competition for food and occupation of breeding areas, shelter and feeding (BITTENCOURT person communication). However, it has not been investigated yet the impacts of introducing Nile tilapia on the fauna of parasites in native ichthyofauna of this natural ecosystem with important species of scientific and applied interest. However, the introduction of trichodinids Paratrichodina africana Kazubski \& El-Tantawy, 1986 (PANTOJA et al., 2012) was reported recently for O. niloticus farmed in this same region of Brazil.

The aim of this study was to investigate the parasites of $O$. niloticus and species of native Cichlidae from the Igarapé Fortaleza basin (State of Amapá) and to identify whether there was transfer of parasites between such ecologically similar fish species inhabiting the same environment.

\section{Materials and Methods}

\section{Characterization of the studied area}

The Igarapé Fortaleza basin, in the State of Amapá, (Eastern Amazon), is composed by a main channel and the floodplain area (Figure 1). This basin is a tributary of the Amazon River, and then the main channel of the basin and Amazon River are both responsible for forming the floodplain area. This floodplain area is a fluvial physical system drained by freshwater and influenced by high rainfall and tides of the Amazon River (TAKYAMA et al., 2004). Several fish, including Cichlidae species are known throughout this basin (main channel and floodplain area), because the floodplain area form a propitious environment to the development of small and medium size fish species being important to subsistence fishing and aquarium. In the rainy season (December to June), waters spread over the plain, when favorable conditions lead to most fish to reproduce earlier in the season. This is the main period for feeding, growth and accumulation of energy reserves used to support the short food supply during the drainage season (GAMA; HALBOTH, 2004) from June to November.

\section{Fish and sampling procedures}

In the period from December 2009 to June 2011, in the main channel of the Igarapé Fortaleza and area under the floodplain action, specimens of $O$. niloticus and Cichlidae species were captured by using cast nets of 30 and $40 \mathrm{~mm}$ and gill nets of 20,25 and $30 \mathrm{~mm}$ (ICMBio License: 23276-1). The caught fish were then 


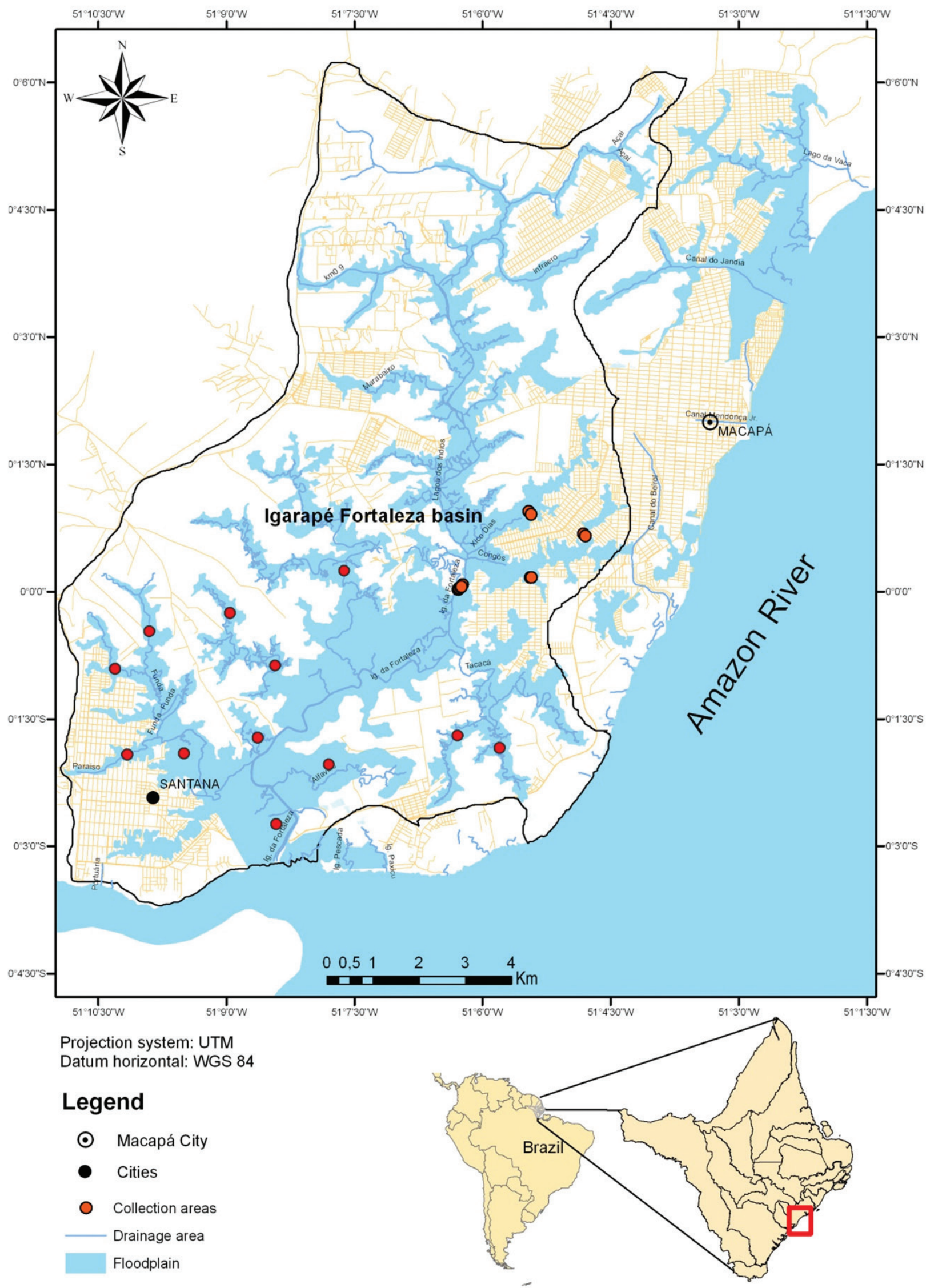

Figure 1. Collection localities of native Cichlidae species and Oreochromis niloticus in the Igarapé Fortaleza basin, eastern Amazon, Brazil. 
transported on ice to the Laboratory of Aquaculture and Fisheries of Embrapa Amapá, Macapá (AP) for parasitological analysis.

\section{Parasitological analysis}

For each caught fish, the mouth and gills were examined for ectoparasites, and gastrointestinal tract for collection of endoparasites. The techniques used for collection, fixation, conservation and staining of parasites were according to previous recommendations (AMATO et al., 1991; EIRAS et al., 2006). For Trichodinidae identification, gills smears were carried out, dried at room temperature and impregnated with silver nitrate using the Klein's method (VAN AS; BASSON, 1989) and other samples were stained with Giemsa (LOM, 1958). The parasitological terminology used throughout follows that described by to Rohde et al. (1995) and Bush et al. (1997).

\section{Physicochemical parameters}

Water physicochemical analyses were performed in main channel of the Igarapé Fortaleza and the floodplain area during the mornings and certain $\mathrm{pH}$ (pH: YSI-100), dissolved oxygen levels and temperature (DO: 200-YSI) of water, ammonia and nitrite levels (HI93715-Hanna) by using digital devices for each purpose. In the main channel of the Igarapé Fortaleza, water temperature ranged from 27.8 to $28.5^{\circ} \mathrm{C}$; $\mathrm{pH} 6.4$ to 6.9; dissolved oxygen levels 1.5 to $2.4 \mathrm{mg} / \mathrm{L}$; total ammonia levels 0.121 to $0.364 \mathrm{mg} / \mathrm{L}$ and nitrite 0.030 to $0.032 \mathrm{mg} / \mathrm{L}$. In floodplain area, the water temperature ranged from 26.0 to $33^{\circ} \mathrm{C}$; $\mathrm{pH} 6.2$ to 7.5 ; dissolved oxygen levels from 0.5 to $4.7 \mathrm{mg} / \mathrm{L}$; total ammonia levels from 0.243 to $0.486 \mathrm{mg} / \mathrm{L}$ and nitrite 0.010 to $0.098 \mathrm{mg} / \mathrm{L}$.

\section{Results}

A total of 576 fish was collected in Igarapé Fortaleza basin, out of which 218 were $O$. niloticus and 358 were species of native cichlids occurring in higher number of species in the main channel of this basin compared to floodplain area (Table 1).

The fauna of parasites of $O$. niloticus was about seven times lower than of the 16 native cichlids species and it consists of monogenoidean species and protozoan ciliates. However, $79.0 \%$ of parasites were helminthes species in native cichlids; $10.5 \%$ were protozoans and the other $10.5 \%$ were species of ectoparasite crustaceans (Table 2). This reduced parasitic fauna in $O$. niloticus occurred exclusively in the gills (ectoparasites). In the native host, there was also high parasitism in the gills, but more than half of helminthes were parasites of the gastrointestinal tract, parasitizing the intestine, pyloric cecum and/or liver of hosts (Figure 2).

The richness of parasite species and infection levels have differed comparing fish (native and exotic) examined in the floodplain area and the main channel of Igarapé Fortaleza basin. In floodplain area, the dominance was of protozoan species due to the predominance of $O$. niloticus in this environment and with infection caused by Ichthyophthirius multifliis Fouquet, 1876, Paratrichodina africana, Trichodina nobilis Chen, 1963 and Trichodina centrostrigeata Basson, Van As \& Paperna, 1983. However, in the main channel, where there is higher prevalence and diversity of native cichlids species, it was higher the level of infection and the richness of helminthes ecto- and endoparasites. These hosts native were parasitized by larval and adult forms of Nematoda, Digenea, Acanthocephala and Cestoidea, while in the hosts of floodplain area only a few Digenea and Nematoda species were found. However, in the gills and intestine of native hosts collected in both environments there were found metacercariae of Digenea in different stages of development. Ectoparasite crustaceans were also found only in

Table 1. Mean weight and total length of Cichlidae species captured at two sites of the Igarapé Fortaleza basin, Amapá State, eastern Amazon, Brazil.

\begin{tabular}{|c|c|c|c|c|c|c|}
\hline \multirow[t]{2}{*}{ Fish species } & \multicolumn{3}{|c|}{ Main channel } & \multicolumn{3}{|c|}{ Floodplain area } \\
\hline & $\mathbf{N}$ & Weight (g) & Length $(\mathrm{cm})$ & $\mathbf{N}$ & Weight (g) & Length $(\mathrm{cm})$ \\
\hline Aequidens sp. & 4 & $71.0 \pm 24.4$ & $13.9 \pm 1.5$ & 3 & $37.7 \pm 5.7$ & $11.7 \pm 0.7$ \\
\hline Aequidens tetramerus & 33 & $57.1 \pm 18.2$ & $13.5 \pm 1.6$ & 59 & $69.0 \pm 27.5$ & $14.5 \pm 2.2$ \\
\hline Astronotus ocellatus & 13 & $212.0 \pm 65.0$ & $20.1 \pm 2.6$ & 4 & $236.35 \pm 104.5$ & $21.5 \pm 4.8$ \\
\hline Chaetobranchus flavescens & 14 & $94.4 \pm 62.6$ & $17.0 \pm 4.4$ & - & - & - \\
\hline Chaetobranchopsis orbicularis & 31 & $105.2 \pm 43.9$ & $16.6 \pm 3.0$ & - & - & - \\
\hline Cichlassoma amazonarum & 6 & $34.6 \pm 7.0$ & $10.7 \pm 1.0$ & 54 & $49.2 \pm 19.6$ & $12.8 \pm 2.2$ \\
\hline Cichlassoma bimaculatum & 8 & $59.0 \pm 21.1$ & $14.1 \pm 2.9$ & - & - & - \\
\hline Geophagus brasiliensis & 01 & $76.0 \pm 0.0$ & $14.5 \pm 0.0$ & - & - & - \\
\hline Heros efasciatus & 3 & $64.6 \pm 43.9$ & $12.1 \pm 4.1$ & - & - & - \\
\hline Hypselecara temporalis & 1 & $56.0 \pm 0.0$ & $13.2 \pm 0.0$ & - & - & - \\
\hline Laetacara curviceps & 17 & $55.4 \pm 24.3$ & $13.6 \pm 2.0$ & 3 & $18.5 \pm 4.0$ & $9.1 \pm 1.2$ \\
\hline Mesonauta sp. & 2 & $34.0 \pm 0.0$ & $12.0 \pm 0.5$ & 29 & $54.6 \pm 31.6$ & $12.6 \pm 2.2$ \\
\hline Mesonauta acora & 7 & $22.0 \pm 7.3$ & $10.0 \pm 1.4$ & 30 & $62.1 \pm 18.7$ & $13.6 \pm 1.5$ \\
\hline Mesonauta guyanae & 9 & $19.3 \pm 7.7$ & $9.5 \pm 2.1$ & - & - & - \\
\hline Oreochromis niloticus & 37 & $275.2 \pm 51.5$ & $23.2 \pm 1.7$ & 181 & $115.4 \pm 77.5$ & $17.2 \pm 4.9$ \\
\hline Pterophyllum scalare & 7 & $11.1 \pm 3.8$ & $8.5 \pm 1.1$ & - & - & - \\
\hline Satanoperca jurupari & 20 & $41.3 \pm 32.8$ & $12.0 \pm 4.0$ & - & - & - \\
\hline
\end{tabular}


native cichlids of the main channel of this Amazonian ecosystem (Table 3, 4).

Most of the parasites were native species and only four parasites were exotic species (Cichlidogyrus tilapiae Paperna, 1960, P. africana, T. nobilis and T. centrostrigeata) occurred in fish of this natural environment after 9-10 years of the invasion of $O$. niloticus. These

Table 2. Richness of parasite species by taxonomic groups in native host fish and the exotic host fish in the Igarapé Fortaleza basin, Amapá State, eastern Amazon, Brazil.

\begin{tabular}{lcc}
\hline \multicolumn{1}{c}{ Taxon } & Native Cichlidae & O. niloticus \\
\hline Protozoa & 4 & 4 \\
Crustacea & 4 & 0 \\
Monogenoidea & 11 & 1 \\
Nematoda & 6 & 0 \\
Digenea & 7 & 0 \\
Acanthocephala & 4 & 0 \\
Cestoidea & 2 & 0 \\
Total number of species & 38 & 5 \\
\hline
\end{tabular}
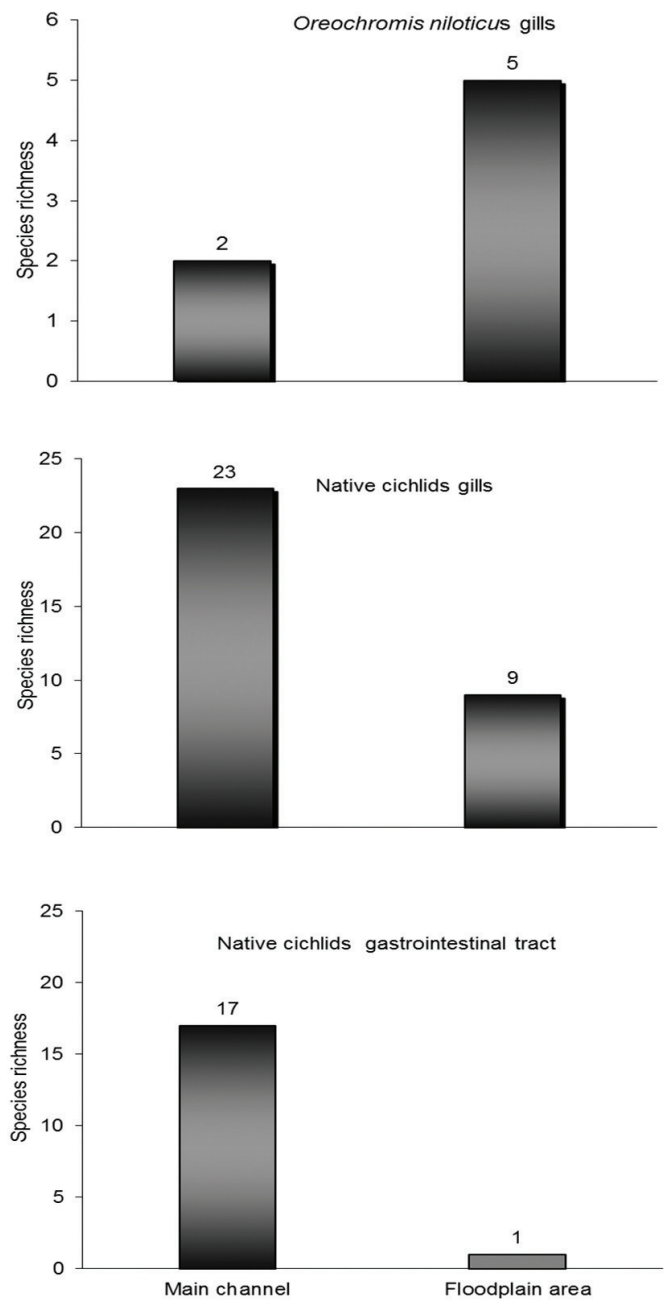

Figure 2. Richness of parasite species according to the local of infection and collection sites of Cichlidae species in the Igarapé Fortaleza basin, Amapá State, eastern Amazon, Brazil. exotic parasites were found only in invasive $O$. niloticus, except T. nobilis that was also transferred to Aequidens tetramerus Heckel, 1840, a native cichlid species. Protozoans Piscinoodinium pillulare Schäperclaus, 1954 and I. multifiliis were also found mainly in natives fish, but both are ectoparasites of unknown origin in Brazil. However, only one native ciliated was found, Tripartiella tetramerii, a trichodinid of $A$. tetramerus (Tables 3, 4).

\section{Discussion}

In Brazil, more than 40 years after introducing O. niloticus, the parasitic fauna of this fish in fish farms consists primarily of species from its place of origin such as P. africana (Trichodinidae), C. tilapiae, Cichlidogyrus aegypticus Ergens, 1981, Cichlidogyrus cirratus Paperna, 1964, Cichlidogyrus halli Price \& Kirk, 1967, Cichlidogyrus thurstonae Ergens, 1981, Cichlidogyrus arthracanthus Paperna, 1960, Scutogyrus longicornis Paperna \& Thurston, 1969, Gyrodactylus cichlidarum Paperna, 1968 and Enterogyrus cichlidarum Paperna, 1963 (Monogenoidea); besides Trichodina compacta Van As \& Basson, 1989, Trichodina magna Van As \& Basson, 1989 (Trichodinidae) and Lamproglena monodi Capart, 1944 (Copepoda), parasites originally described as species of cichlids from Africa, Taiwan and the Philippines, as wells as Clinostomum complanatum Rudolphi, 1814, Diplostomum sp. (Digenea), Argulus spinulosus Silva, 1980 (Branchiura), Dolops carvalhoi Lemos de Castro, 1949 (Branchiura) and Ergasilus sp. (Copepoda) acquired from species of Brazilian ichthyofauna (PANTOJA et al., 2012).

In its place of origin, the Nile River delta (Egypt), O. niloticus has been parasitized by the following species of helminthes: $C$. tilapiae, C. aegypticus, C. cirratus, C. halli, C. thurstonae, C. arthracanthus, S. longicornis, G. cichlidarum and E. cichlidarum, Paracamallanus cyathopharynx Baylis, 1923 (Nematoda), Orientocreadium batrochoides Tubangul, 1931 (Digenea), Polyonchobotriun sp. (Cestoidea), Acanthosentis tilapiae Baylis, 1948 (Acanthocephala), I. multifiliis, T. centrostrigeata, T. rectinucinata and Chilodonella hexastica Kiernik, 1909 (Ciliophora), L. monodi, Ergasilus sarsi Capart, 1944 (Copepoda) and Lernaea cyprinacea Linnaeus, 1758 (Copepoda) (EL-SEIFY et al., 2011; EISSA et al., 2011; SOLIMAN; IBRAHIM, 2012). Therefore, with the introduction of $O$. niloticus in Brazilian fish farms, there was a loss of its species of endohelminthes and crustaceans, which were then replaced by the common species of native ichthyofauna. However, such results in fish farms may not be representative of conditions in natural Brazilian ecosystems that may be invaded by $O$. niloticus.

In the Igarapé Fortaleza basin, the parasites of $O$. niloticus were $C$. tilapiae, T. centrostrigeata, $P$. africana, T. centrostrigeata and T. nobilis, which are then the species from biotic unit of this host fish (Galli's symbiota concept), besides I. multifiliis, a ciliated with worldwide distribution. However, such exotic parasites have shown little immediate consequence for the native cichlids, since only once $A$. tetramerus acquired $T$. nobilis. The low acquisition of exotic parasites by the rich ichthyofauna of native cichlids is due to the introduction of these parasites in a community of hosts with great diversity of native ectoparasites, especially species of monogenoideans, metacercariae of digeneans in different stages, protozoans I. multifiliis, P. pillulare and T. tetramerii, thus resulting in 
Table 3. Parasite species of native and exotic Cichlidae in floodplain area from the Igarapé Fortaleza basin, Amapá State, eastern Amazon, Brazil.

\begin{tabular}{|c|c|c|c|}
\hline Parasite species & $\mathbf{P}(\%)$ & MI & Host fish \\
\hline \multicolumn{4}{|l|}{ Trichodinidae } \\
\hline Paratrichodina africana & 29.5 & 8333.4 & Oreochromis niloticus \\
\hline Paratrichodina africana and Trichodina nobilis & 45.9 & 11358.7 & Oreochromis niloticus \\
\hline Paratrichodina africana and Trichodina centrostrigeata & 100 & 18422.8 & Oreochromis niloticus \\
\hline Tripartiella tetramerii and Trichodina nobilis & 10.2 & 5974.8 & Aequidens tetramerus \\
\hline \multicolumn{4}{|l|}{ Dinoflagellida } \\
\hline \multirow[t]{2}{*}{ Piscinoodinium pillulare } & 14.8 & 422.2 & Cichlassoma amazonarum \\
\hline & 10.0 & 352.6 & Mesonauta acora \\
\hline \multicolumn{4}{|l|}{ Ciliophora } \\
\hline \multirow[t]{8}{*}{ Ichthyophthirius multifiliis } & 70.7 & 31040.4 & Oreochromis niloticus \\
\hline & 100 & 64607.3 & Astronotus ocellatus \\
\hline & 100 & 8303.3 & Mesonauta acora \\
\hline & 100 & 18619.0 & Mesonauta sp. \\
\hline & 100 & 17600.3 & Laetacara curviceps \\
\hline & 98.1 & 36453.9 & Cichlassoma amazonarum \\
\hline & 100 & 22493.3 & Aequidens tetramerus \\
\hline & 100 & 5026.3 & Aequidens sp. \\
\hline \multicolumn{4}{|l|}{ Monogenoidea } \\
\hline Cichlidogyrus tilapiae & 3.3 & 0.11 & Oreochromis niloticus \\
\hline Gussevia asota & 100 & 19.5 & Astronotus ocellatus \\
\hline \multirow[t]{2}{*}{ Sciadicleithrum joanae } & 26.7 & 6.5 & Mesonauta acora \\
\hline & 6.9 & 2.5 & Mesonauta sp. \\
\hline Gussevia disparoides & 16.7 & 1.8 & Cichlassoma amazonarum \\
\hline \multicolumn{4}{|l|}{ Nematoda } \\
\hline \multirow[t]{2}{*}{ Procamallanus sp. } & 3.4 & 7.0 & Mesonauta sp. \\
\hline & 1.8 & 1.0 & Cichlassoma amazonarum \\
\hline \multicolumn{4}{|l|}{ Digenea } \\
\hline \multirow[t]{5}{*}{ Posthodiplostomum sp. (metacercariae) } & 10.3 & 2.3 & Mesonauta sp. \\
\hline & 35.2 & 3.6 & Cichlassoma amazonarum \\
\hline & 66.7 & 1.0 & Laetacara curviceps \\
\hline & 75.0 & 27.0 & Astronotus ocellatus \\
\hline & 53.3 & 6.7 & Mesonauta acora \\
\hline
\end{tabular}

P: Prevalence, MI: Mean intensity.

shortage of available niche for newcomer ectoparasites. Furthermore, $P$. africana, the most frequent trichodinids in $O$. niloticus, has parasite specificity. For native parasites, it was also difficult to colonize $O$. niloticus, because none of these parasites infected this invasive host so far. Thus, while the parasitic fauna of this invasive was formed exclusively by ectoparasites, in native host the infections were caused by ectoparasites and endoparasites, but with higher richness of endohelminthic species, mainly in the main channel where the highest diversity of native fish species occurred.

The parasite species with rich fauna generally occur in a few species of hosts fish, since they are experts, while the parasites in poor fauna are mostly general species (KENNEDY; POJMANSKA, 1996; POULIN, 1997), but this relation does not occur in fish that have suffered frequent translocations to the same environment (POULIN, 1997). In the Igarapé Fortaleza basin, the community of parasites in $O$. niloticus was dominated by species of gills opportunistic ciliates.

Species of native cichlids were also parasitized by protozoa (I. multifiliis, P. pillulare and T. tetramerii) but its parasitic fauna was dominated mainly by a rich diversity of Monogenoidea, adults and larvae of Nematoda, Digenea, Cestoidea and Acanthocephala, indicating that they are intermediate or paratenic hosts of endohelminthic species in the area of this study. On the other hand, O. niloticus, in its original site this host accumulates in the gills eight species of monogenoideans and four species of helminthic endoparasites. In an artificial lake in Maringá, Southern Brazil, O. niloticus was parasitized by $C$. sclerosus, C. longicornis, Cichlidogyrus sp.; besides larvae of Contracaecum sp. and Cestoidea, endohelminth that also parasitized Geophagus brasiliensis Quoy \& Gaimard, 1824 and Crenicichla britskii Kullander, 1982, species of cichlids of ichthyofauna of Brazil (GRAÇA; MACHADO, 2007). For this tilapia introduced into the Guarapiranga Reservoir, southeastern Brazil, the parasitic fauna is constituted only by Cichlidogyrus sp., Trichodina sp., I. multifiliis, Cryptobia sp. and Henneguya sp. (RANZANI-PAIVA et al., 2005). The parasite fauna of native cichlid Vieja maculicauda Regan, 1905 in the Panama Canal is rich in species of Monogenoidea, Trematoda, Nematoda and Acanthocephala. However, the helminth fauna of the invasive 
Table 4. Parasite species of native and exotic Cichlidae in the main channel from the Igarapé Fortaleza basin, Amapá State, eastern Amazon, Brazil.

\begin{tabular}{|c|c|c|c|}
\hline Parasite species & $\mathbf{P}(\%)$ & MI & Host fish \\
\hline \multicolumn{4}{|l|}{ Trichodinidae } \\
\hline Paratrichodina africana & 100 & 2019.4 & Oreochromis niloticus \\
\hline \multicolumn{4}{|l|}{ Dinoflagellida } \\
\hline \multirow[t]{6}{*}{ Piscinoodinium pillulare } & 57.1 & 324.5 & Pterophyllum scalare \\
\hline & 14.3 & 758.0 & Chaetobranchus flavescens \\
\hline & 14.3 & 160.0 & Mesonauta acora \\
\hline & 64.5 & 5254.0 & Chaetobranchopsis orbicularis \\
\hline & 55.0 & 1347.7 & Satanoperca jurupari \\
\hline & 12.5 & 320.0 & Cichlassoma bimaculatum \\
\hline \multicolumn{4}{|l|}{ Ciliophora } \\
\hline \multirow[t]{17}{*}{ Ichthyophthirius multifiliis } & 100 & 16142.2 & Oreochromis niloticus \\
\hline & 100 & 7105.0 & Geophagus brasiliensis \\
\hline & 100 & 3330.1 & Pterophyllum scalare \\
\hline & 76.9 & 8554.2 & Astronotus ocellatus \\
\hline & 100 & 40866.7 & Heros efasciatus \\
\hline & 100 & 45562.2 & Chaetobranchus flavescens \\
\hline & 100 & 13458.4 & Mesonauta acora \\
\hline & 100 & 10875.0 & Mesonauta sp. \\
\hline & 55.5 & 2034.0 & Mesonauta guyanae \\
\hline & 100 & 20541.3 & Chaetobranchopsis orbicularis \\
\hline & 100 & 8229.7 & Cichlassoma amazonarum \\
\hline & 100 & 51512.1 & Cichlassoma bimaculatum \\
\hline & 100 & 22614.6 & Aequidens tetramerus \\
\hline & 100 & 1568.0 & Aequidens sp. \\
\hline & 100 & 5935.4 & Laetacara curviceps \\
\hline & 80.0 & 10508.6 & Satanoperca jurupari \\
\hline & 100 & 1305.0 & Hypselecara temporalis \\
\hline \multicolumn{4}{|l|}{ Branchiura } \\
\hline \multirow[t]{2}{*}{ Dolops longicauda } & 6.4 & 1.0 & Chaetobranchopsis orbicularis \\
\hline & 6.0 & 2.0 & Aequidens tetramerus \\
\hline Argulus multicolor & 7.7 & 1.0 & Astronotus ocellatus \\
\hline \multicolumn{4}{|l|}{ Copepoda } \\
\hline Ergasilus sp. & 28.6 & 3.5 & Aequidens sp. \\
\hline \multicolumn{4}{|l|}{ Isopoda } \\
\hline Braga patagonica & 7.1 & 1.0 & Chaetobranchus flavescens \\
\hline \multicolumn{4}{|l|}{ Monogenoidea } \\
\hline Gussevia asota & 92.3 & 63.1 & Astronotus ocellatus \\
\hline \multirow[t]{3}{*}{ Gussevia disparoides } & 100 & 37.3 & Heros efasciatus \\
\hline & 66.7 & 4.0 & Cichlassoma amazonarum \\
\hline & 82.3 & 14.1 & Laetacara curviceps \\
\hline Sciadicleithrum joanae & 85.7 & 25.7 & Mesonauta acora \\
\hline Sciadicleithrum geophagi & 58.1 & 12.8 & Chaetobranchopsis orbicularis \\
\hline Gussevia disparoides and Gussevia alioides & 78.8 & 19.4 & Aequidens tetramerus \\
\hline Gussevia elephus and Gussevia spiralocirra & 78.6 & 5.2 & Chaetobranchus flavescens \\
\hline Gussevia arilla & 62.5 & 2.8 & Cichlassoma bimaculatum \\
\hline Gussevia spiralocirra & 100 & 23.2 & Aequidens sp. \\
\hline Sciadicleithrum satanoperca & 40.0 & 5.4 & Satanoperca jurupari \\
\hline Sciadicleithrum iphthimum & 100 & 13.4 & Pterophyllum scalare \\
\hline Urocleidoides sp. & 33.3 & 1.3 & Mesonauta guyanae \\
\hline \multicolumn{4}{|l|}{ Nematoda } \\
\hline \multirow[t]{2}{*}{ Icthyouris sp. } & 85.7 & 6.7 & Pterophyllum scalare \\
\hline & 33.3 & 4.0 & Heros efasciatus \\
\hline
\end{tabular}

P: Prevalence, MI: Mean intensity. 
Table 4. Continued...

\begin{tabular}{|c|c|c|c|}
\hline Parasite species & $\mathbf{P}(\%)$ & MI & Host fish \\
\hline & 15.0 & 10.3 & Satanoperca jurupari \\
\hline & 44.4 & 35.3 & Mesonauta guyanae \\
\hline Icthyouris sp.1, Icthyouris sp.2, Procamallanus sp. and Pseudoproleptus sp. & 71.4 & 16.2 & Mesonauta acora \\
\hline Procamallanus sp. & 50.0 & 2.7 & Cichlassoma amazonarum \\
\hline \multirow[t]{2}{*}{ Pseudoproleptus sp. } & 51.5 & 8.7 & Aequidens tetramerus \\
\hline & 76.5 & 25.8 & Laetacara curviceps \\
\hline \multirow[t]{2}{*}{ Anisakidae gen. sp. (larvae) } & 9.1 & 13.0 & Aequidens tetramerus \\
\hline & 10.0 & 5.0 & Laetacara curviceps \\
\hline Contracaecum sp. & 38.5 & 2.4 & Astronotus ocellatus \\
\hline \multicolumn{4}{|l|}{ Cestoidea } \\
\hline \multirow[t]{2}{*}{ Proteocephalidea gen. sp. (plerocercoid) } & 12.1 & 1.0 & Aequidens tetramerus \\
\hline & 5.0 & 1.0 & Laetacara curviceps \\
\hline Proteocephalus gibsoni & 23.1 & 7.0 & Astronotus ocellatus \\
\hline \multicolumn{4}{|l|}{ Digenea } \\
\hline \multirow[t]{2}{*}{ Digenea gen. sp. } & 14.3 & 4.0 & Pterophyllum scalare \\
\hline & 93.9 & 53.2 & Aequidens tetramerus \\
\hline Cladorchiidae gen. sp. (metacercariae) & 100 & 5.0 & Heros efasciatus \\
\hline Acanthostomidae gen. sp. and Posthodiplostomum sp. (metacercariae) & 92.3 & 38.8 & Astronotus ocellatus \\
\hline Acanthostomidae gen. sp. and Thometrema sp. (metacercariae) & 57.1 & 42.0 & Aequidens sp. \\
\hline \multirow[t]{3}{*}{ Cladorchiidae gen. sp. and Posthodiplostomum sp. (metacercariae) } & 100 & 26.0 & Mesonauta acora \\
\hline & 57.1 & 23.8 & Mesonauta acora \\
\hline & 83.3 & 8.6 & Cichlassoma amazonarum \\
\hline \multirow[t]{2}{*}{ Clinostomum marginatum } & 9.6 & 8.7 & Chaetobranchopsis orbicularis \\
\hline & 7.7 & 2.0 & Astronotus ocellatus \\
\hline Thometrema sp. & 30.7 & 6.2 & Astronotus ocellatus \\
\hline Derogenidae gen. sp. (metacercariae) & 20.0 & 3.3 & Satanoperca jurupari \\
\hline \multirow{2}{*}{ Posthodiplostomum sp. (metacercariae) } & 100 & 11.0 & Mesonauta sp. \\
\hline & 41.9 & 70.3 & Chaetobranchopsis orbicularis \\
\hline \multicolumn{4}{|l|}{ Acanthocephala } \\
\hline \multirow[t]{4}{*}{ Gorytocephalus spectabilis } & 33.3 & 5.0 & Heros efasciatus \\
\hline & 28.6 & 7.0 & Mesonauta acora \\
\hline & 12.1 & 2.5 & Aequidens tetramerus \\
\hline & 10.0 & 44.0 & Satanoperca jurupari \\
\hline Echinorhynchus paranensis and Gorytocephalus spectabilis & 50.0 & 31.1 & Chaetobranchus flavescens \\
\hline Echinorhynchus paranensis and Neoechinorhynchus pterodoridis & 77.4 & 22.8 & Chaetobranchopsis orbicularis \\
\hline
\end{tabular}

P: Prevalence, MI: Mean intensity.

O. niloticus consisted of Trematoda and native Nematoda and three Monogenoidea species of its place of origin, out of which only Cichlidogyrus dossoui Douellou, 1993 was acquired by $V$. maculicauda (ROCHE et al., 2010). Therefore, this parasite fauna in $O$. niloticus was higher than that in the present study, which shows that during the early establishment of $O$. niloticus in the Igarapé Fortaleza basin the small number of parasite species is one of the factors favoring their rapid demographic growth and population explosion in this new environment.

Monogenoideans are parasites with direct life cycle and resistant to elimination when translocated (PÉREZPONCE DE LEÓN et al., 2000). Thus, species of the genus Cichlidogyrus translocated with $O$. niloticus colonized species of endemic cichlids of Mexico (JIMÉNEZ-GARCÍA et al., 2001) and Panama (ROCHE et al., 2010), due to its relative parasite specificity. In contrast, $C$. tilapiae, the only species of helminth parasitizing this invasive fish in the region of this study, was not competent to invade any of the 16 species of native cichlids, fish ecologically similar. However, in Brazilian fish farms, O. niloticus has been parasitized by $C$. tilapiae and by $C$. sclerosus, besides other species still unidentified (PANTOJA et al., 2012), possibly the $C$. longicornis. Thus, the results of this fish introduction in Brazilian fish farms do not reflect what occurs in the natural environment; it indicates loss of monogenoideans species with the translocation of this tilapia from other regions of Brazil to the studied area. Therefore, the acquisition and transmission of exotic parasites depend on a complex set of factors, including biological aspects of host and parasite, host-parasite interaction and scalespace (JIMÉNEZ-GARCÍA et al., 2001; ROCHE et al., 2010; GENDRON et al., 2012; PATERSON et al., 2012).

The colonization of exotic hosts by native parasites is a process that can take a long time (KENNEDY; POJMANSKA 1996) 
or be slow (GENDRON et al., 2012), caused by variations in the host-parasite system to species of investigated fish. Invasive fish need some time to acquire generalist helminthic parasites of native ichthyofauna (KENNEDY; POJMANSKA, 1996; PATERSON et al., 2012), especially endohelminthes. Thus, in the Igarapé Fortaleza basin, due to the recent history of invasion of $O$. niloticus (less than a decade), there was not enough time to acquire common helminth species to their native competitors, which had a rich fauna species of endohelminthes, parasites of complex life cycle involving fish communities and also invertebrates (PÉREZPONCE DE LEÓN et al., 2000; PATERSON et al., 2012).

Invasive fish are poor in species of helminthes (GUÉGAN; KENNEDY, 1993; KENNEDY; POJMANSKA 1996; GENDRON et al., 2012; PATERSON et al., 2012), mainly fish that have in their fauna specialist endohelminthes, because these fish are not susceptible to invasion by species of specialist parasites of native fish. Pérez-Ponce de León et al. (2000) found only a single species of endohelminth (Nematoda) parasitizing O. niloticus introduced on the Lake Pátzcuaro (Mexico), while for the same host of lakes of the Panama Canal, Roche et al. (2010) reported four species of Digenea and four species of Nematoda. Therefore, more time is necessary for this invasive tilapia being colonized by species of endohelminthes common to the local ichthyofauna of this study; however, the period is difficult to estimate.

Trichodinidae are predominantly opportunistic protozoans that have broad geographic distribution and generally parasitize the skin of their native and exotic hosts. Overall, the most specialized species parasitize gills of certain groups of hosts, and when they are translocated, remain with their hosts of origin (VAN AS; BASSON, 1987). Paratrichodina africana is a parasite of gills of $O$. niloticus, but rarely of skin (KAZUBSKI; EL-TANTAWY, 1986), is it strongly associated with Oreochromis hosts. Trichodina centrostrigeata from gills, skin and fins of species of Oreochromis mossambicus Peters, 1852, Pseudocrenilabrus philander Weber, 1897, Tilapia rendalli Boulenger, 1897, Tilapia sparrmanii Smith, 1840 (Cichlidae) and Cyprinus carpio Linnaeus, 1758 from Africa (BASSON et al., 1983); subsequently, it has been found parasitizing O. niloticus in Africa (EL-TANTAWY; KAZUBSKI, 1986), Philippines (BONDADREANTASO; ARTHUR, 1989) and now in Brazil, due to its translocation. Thus, this species seems to be more specific to the Cichlidae species (BONDAD-REANTASO; ARTHUR, 1989).

Trichodina nobilis originally described to Cyprinidae is associated with skin and gills of fish species of this family, but it has the skin as a preferential habitat (BASSON; VAN AS, 1994; MARTINS et al., 2012). Thus, it has been reported that this trichodinid parasites the skin, gills and fins of different Cichlidae species (BASSON; VAN AS, 1994), skin of Poecilidae (MARTINS et al., 2012), as well as gills of $O$. niloticus of Nile River (EL-SEIFY et al., 2011) and also the Amazon estuary in Northern Brazil. Van As and Basson (1987) reported that the species of Tripartiella can vary the degree of specificity, because some species are restricted to the gills of particular genus or even to a single host. In fact, it is observed in the studies of Vulpe (2002), Mohilal and Hemananda (2012), and Mitra et al. (2012) that Tripartiella obtusa Ergens \& Lom, 1970, Tripartiella copiosa Lom, 1959 and Tripartiella bulbosa Lom, 1959 are often associated with species of Cyprinidae of genera Cirrhinus, Labeo, Catla and Cyprinus. Furthermore,
T. tetramerii was parasite only of $A$. tetramerus, a native cichlid in region of this study.

Trichodinidae ciliates can be considered the most common parasites in fish of different environments. In gills of $O$. niloticus of the Igarapé Fortaleza basin, it was found higher levels of infections caused by $P$. africana when associated with $T$. centrostrigeata or T. nobilis. Similarly, in the gills of $A$. tetramerus the parasitism by $T$. tetramerii (native) was associated to infection by $T$. nobilis, but levels of infection were lower compared to exotic tricodinids in gills of $O$. niloticus. However, for the same tilapia species from the Brazilian reservoir, the levels of infection by Trichodina sp. caused by low temperature of the region (RANZANI-PAIVA et al., 2005) were lower than that in this study. In poor environmental conditions of intensive culture and high stocking density (VAN AS; BASSON, 1987; TAVARES-DIAS et al., 2001; JERÔNIMO et al., 2012) or even in a natural environment (RANZANI-PAIVA et al., 2005), the intensity of these ciliates can increase rapidly. Because its reproduction is favored by excess organic matter (TAVARESDIAS et al., 2001; JERÔNIMO et al., 2012; MARTINS et al., 2012), especially at high temperatures, as it was the case of this study.

Monogenoidea species were not found in $O$. niloticus of the main channel of the Igarapé Fortaleza. On the other hand, in this invasive fish of floodplain area, the low levels of gill infection by C. tilapiae were associated with high parasitism by opportunistic protozoa (I. multifiliis, P. africana, T. centrostrigeata and T. nobilis), parasites known for their strong influence on low environmental quality (TAVARES-DIAS et al., 2001; JERÔNIMO et al., 2012). Possibly, C. tilapiae has suffered pressure in this new environment and also by habitat competition (in gills) with the ciliates species. In this same region, for this tilapia from fish farms, it was reported high levels of infection caused by $C$. tilapiae associated with low parasitism by Trichodina sp. (probably T. centrostrigeata), $P$. africana and I. multifiliis (PANTOJA et al., 2012), indicating that infections caused by ciliates were secondary. Fish with acute and subacute infection become more susceptible (TAVARESDIAS et al., 2001) to infections by opportunistic species of protozoa showed in this study. In gills of $O$. niloticus from reservoir, the levels of infections by Cichlidogyrus sp. were also low due to the occurrence in some months of the year (RANZANI-PAIVA et al., 2005). Sanchez-Ramirez et al. (2004) reported that in O. niloticus kept experimentally in polluted environment, the abundance of C. sclerosus decreased, but the infection was chronic. Therefore, C. tilapiae may be sensitive to environmental eutrophication and may have seasonal infection pattern, this is why it was not found parasitizing this invasive fish in the main channel of the natural investigated ecosystem.

The differences in parasitism between fish of the main channel and floodplain area should be due to the highest diversity of native hosts in the main channel, location with low occupancy by invasive $O$. niloticus. The low acquisition of exotic parasites by the rich fauna of native cichlids species was expected, since our recent studies (PANTOJA et al., 2012) indicated a reduced fauna of exotic parasites in farmed O. niloticus in Brazil. However, it was unexpected non colonization in $O$. niloticus by parasite species common to native ichthyofauna, since this exotic fish is in this region for almost a decade. Further studies are needed on the factors that have limited the richness of the community of 
parasites in $O$. niloticus and influenced the colonization period in this host to understand the mechanisms of recruitment controlling parasites in introduced fish and the influence on the parasitic fauna of other species of native ichthyofauna.

This was the first report on T. nobilis (Trichodinidae) for A. tetramerus and O. niloticus; T. centrostrigeata (Trichodinidae) for O. niloticus; P. pillulare (Dinoflagellida) for Cichlassoma amazonarum, Mesonauta acora, Pterophyllum scalare, Chaetobranchopsis orbicularis, Satanoperca jurupari, Cichlassoma bimaculatum and Chaetobranchus flavescens; I. multifiliis (Ciliophora) for $M$. acora, Laetacara curviceps, C. amazonarum, A. tetramerus, G. brasiliensis, P. scalare, Heros efasciatus, C. flavescens, Mesonauta guyanae, C. orbicularis, C. bimaculatum, S. jurupari and Hypselecara temporalis; Sciadicleithrum joanae (Monogenoidea) for M. acora; Gussevia disparoides (Monogenoidea) for C. amazonarum, A. tetramerus, $L$. curviceps and $H$. efasciatus; $G$. alioides (Monogenoidea) for A. tetramerus; Gussevia elephus (Monogenoidea) for C. flavescens; Gussevia spiralocirra (Monogenoidea) for C. flavescens; Gussevia arilla (Monogenoidea) for C. bimaculatum; Sciadicleithrum satanoperca (Monogenoidea) for S. jurupari; Urocleidoides sp. (Monogenoidea) for M. guyanae; Posthodiplostomum sp. (Diplostomidae) for C. amazonarum, M. acora and C. orbicularis; Dolops longicauda (Branchiura) for A. tetramerus and C. orbicularis; Braga patagonica (Isopoda) for C. flavescens; Proteocephalus gibsoni (Proteocephalidea) for Astronotus ocellatus; Clinostomum marginatum (Clinostomidae) for C. flavescens and A. ocellatus; Gorytocephalus spectabilis (Neoechinorhynchidae) for $H$. efasciatus, $M$. acora, A. tetramerus, S. jurupari and C. flavescens, and Echinorhynchus paranensis (Echinorhynchinae) for C. flavescens and C. orbicularis.

\section{Acknowledgments}

This study was developed in accordance with the principles recommended by the Brazilian College of Animal Experimentation (COBEA). The authors thank the National Council for Scientific and Technological Development (CNPq, Brazil) for supporting this project (\# 556827/2009-0). Marcos Tavares-Dias was supported by a Research fellowship from CNPq.

\section{References}

Amato JFR, Boeger WA, Amato SB. Protocolos para laboratório, coleta e processamento de parasitos de pescado. Seropédica: UFRRJ; 1991.

Basson L, Van As JG, Paperna I. Trichodinid ectoparasites of cichlid and cyprinid fishes in South Africa and Israel. Syst Parasitol 1983; 5(4): $245-$ 257. http://dx.doi.org/10.1007/BF00009159

Basson L, Van As JG. Trichodinid ectoparasites (Ciliophora: Peritrichida) of wild and cultured freshwater fishes in Taiwan, with notes on their origin. Syst Parasitol 1994; 2(3)8: 197-222.

Bondad-Reantaso MG, Arthur JR. Trichodinids (Protozoa: Ciliophora: Peritrichida) of Nile tilapia (Oreochromis niloticus) in the Philippines. Asian Fish Sci 1989; 3(1): 27-44.

Bush AO, Lafferty KD, Lotz JM, Shostak W. Parasitology meets ecology on its own terms: Margolis et al. Revisited. J Parasitol 1997; 83(4): 575583. PMid:9267395. http://dx.doi.org/10.2307/3284227
Eiras JC, Takemoto RM, Pavanelli GC. Métodos de estudo e técnicas laboratoriais em parasitologia de peixes. Maringá: EdUEM; 2006.

Eissa IAM, Mona SZ, Noor ED, Ibrahin AZ, Osman KAH. Field study on cadmium pollution in relation to internal parasitic diseases in cultured Nile tilapia at Kafr El-Sheikh Governorate. J Am Sci 2011; 7(4): 650-660.

El-Seify MA, Zaki MS, Desouky ARY, Abbas HH, Hady OKA, Zaid AAA. Seasonal variations and prevalence of some external parasites affecting freshwater fishes reared at upper Egypt. Life Sci J 2011; 8(3): 397-400.

El-Tantawy SAM, Kazubski SL. The trichodinid ciliates from fish, Tilapia nilotica from the Nile Delta (Egypt). Acta Protozool 1986; 25(4): 439-444.

Galli P, Stefani F, Benzoni F, Zullini A. Introduction of alien hostparasite complexes in a natural environment and the symbiota concept. Hydrobiologia 2005; 548(1): 293-299. http://dx.doi.org/10.1007/ s10750-005-3645-0

Galli P, Strona G, Benzoni F, Crosa G, Stefani F. Monogenoids from freshwater fish in Italy, with comments on alien species. Comp Parasitol 2007; 74(2): 264-272. http://dx.doi.org/10.1654/4281.1

Gama CS, Halboth DA. Ictiofauna das ressacas das bacias do Igarapé da Fortaleza e do rio Curiaú. In: Takiyama LR, Silva AQ. Diagnóstico de ressacas do estado do Amapá: bacias do Igarapé da Fortaleza e do Curiaú. Macapá: GEA/SETEC/IEPA; 2004. p. 33-66.

Gendron AD, Marcogliese DJ Thomas M. Invasive species are less parasitized than native competitors, but for how long? The case of the round goby in the Great Lakes-St. Laurence basin. Biol Invasions 2012; 14(2): 367-384. http://dx.doi.org/10.1007/s10530011-0083-y

Graça RJ, Machado MH. Ocorrência e aspectos ecológicos de metazoários parasitos de peixes do lago do Parque do Ingá, Maringá, estado do Paraná. Acta Sci Biol Sci 2007; 29(3): 321-326. http://dx.doi.org/10.4025/ actascibiolsci.v29i3.507

Guégan JF, Kennedy CR. Maximum local helminth parasite community richness in British freshwater fish: a test of the colonization time. Parasitology 1993; 106(Pt1): 91-100. PMid:8479807. http://dx.doi. org/10.1017/S0031182000074862

Jerônimo GT, Marchiori NC, Pádua SB, Dias Neto J, Pilarski F, Ishikawa MM et al. Trichodina colisae (Ciliophora: Trichodinidae): new parasite records for two freshwater fish species farmed in Brazil. Rev Bras Parasitol Vet 2012; 21(4): 366-371. PMid:23207983. http://dx.doi.org/10.1590/ S1984-29612012005000008

Jiménez-García MI, Vidal-Martínez VM, López-Jiménez S. Monogeneans in introduced and native cichlids in Mexico: evidence for transfer. J Parasitol 2001; 87(4): 907-909. PMid:11534657.

Kazubski SL, El-Tantawy AM. The ciliate Paratrichodina africana sp. n. (Peritricha, Trichodinidae) from Tilapia fish (Cichlidae) from Africa. Acta Protozool 1986; 25(4): 433-438.

Kennedy CR, Pojmanska T. Richness and diversity of helminth parasite communities in the common carp and in three more recently introduced carp species. J Fish Biol 1996; 48(1): 89-100. http://dx.doi. org/10.1111/j.1095-8649.1996.tb01421.x

Lom J. A contribution to the systematics and morphology of endoparasitic trichodinids from amphibians, with a proposal of uniform specific characteristics. J Protozool 1958; 5(4): 251-263. http://dx.doi. org/10.1111/j.1550-7408.1958.tb02563.x

Martins ML, Marchiori N, Roumbedakis K, Lami F. Trichodina nobilis Chen, 1963 and Trichodina reticulata Hirschmann et 
Partsch, 1995 from ornamental freshwater fishes in Brazil. Braz J Biol2012; 72(2): 281-286. PMid:22735135. http://dx.doi.org/10.1590/ S1519-69842012000200008

Mendoza-Franco EF, Vidal-Martínez VM, Cruz-Quintana Y, Prats León FL. Monogeneans on native and introduced freshwater fishes from Cuba with the description of a new species of Salsuginus Beverly-Burton, 1984 from Limia vittata (Poeciliidae). Syst Parasitol 2006; 64(3): 181-190. PMid:16786283. http://dx.doi.org/10.1007/s11230-006-9030-1

Mitra AK, Bandyopadhyay PK, Gong Y, Bhowmik B. Occurrence of trichodinid ciliophorans (Ciliophora: Peritrichida) in the freshwater fishes of the River Churni with description of Trichodina glossogobae sp. nov. in West Bengal, India. J Parasit Dis 2012; 36(1): 34-43. PMid:23542238 PMCid:PMC3284600. http://dx.doi.org/10.1007/s12639-011-0073-0

Mohilal NE, Hemananda T. Record of the species of Tripartiella (Lom, 1959) from fishes of Manipur. J Parasit Dis 2012; 36(1): 87-93. PMid:23542123 PMCid:PMC3284617. http://dx.doi.org/10.1007/ s12639-011-0088-6

Pantoja WMF, Neves LR, Dias MKR, Marinho RGB, Montagner D, Tavares-Dias M. Protozoan and metazoan parasites of Nile tilapia Oreochromis niloticus cultured in Brazil. Rev MVZ Córdoba 2012; 17(1): 2812-2819.

Paterson RA, Townsend CR, Tompkins DM, Poulin R. Ecological determinants of parasite acquisition by exotic fish species. Oikos 2012; 121(11): 1889-1895. http://dx.doi.org/10.1111/j.16000706.2012.20143.x

Pérez-Ponce de León G, Garcia-Prieto L, Léon-Règagnon V, Choudhury A. Helminth communities of native and introduced fishes in Lake Pátzcuaro, Michoacán, México.J Fish Biol 2000; 57(2): 303-325. http:// dx.doi.org/10.1006/jfbi.2000.1325

Poulin R. Parasite faunas of freshwater fish: The relationship between richness and the specificity of parasites. Int J Parasitol 1997; 27(9): 10911098. http://dx.doi.org/10.1016/S0020-7519(97)00070-2

Poulin R, Paterson RA, Townsend CR, Tompkins DM, Kelly W. Biological invasions and the dynamics of endemic diseases in freshwater ecosystems. Freshwater Biol 2011; 56(4): 676-688. http://dx.doi. org/10.1111/j.1365-2427.2010.02425.x

Ranzani-Paiva MJT, Felizardo NN, Luque JL. Parasitological and hematological analysis of Nile tilapia Oreochromis niloticus Linnaeus, 1757 from Guarapiranga reservoir, São Paulo State, Brazil. Acta Sci Biol Sci 2005; 27(3): 231-237. http://dx.doi.org/10.4025/ actascibiolsci.v27i3.1334
Ribeiro F, Leunda PM. Non-native fish impacts on Mediterranean freshwater ecosystems: current knowledge and research needs. Fish Manag Ecol 2012; 19(2): 142-156. http://dx.doi.org/10.1111/j.13652400.2011.00842.x

Roche DG, Leung B, Mendoza-Franco EF, Torchin ME. Higher parasite richness, abundance and impact in native versus introduced cichlid fishes. Int J Parasitol 2010; 40(13): 1525-1530. PMid:20600073. http://dx.doi. org/10.1016/j.ijpara.2010.05.007

Rohde K, Hayward C, Heap M. Aspects of the ecology of metazoan ectoparasites of marine fishes. Int J Parasitol 1995; 25(8): 945-970. http:// dx.doi.org/10.1016/0020-7519(95)00015-T

Sanchez-Ramirez C, Vidal-Martinez VM, Aguirre-Macedo ML, Rodrigues-Canul RP, Gold-Bouchot G, Sures B. Cichlidogyrus sclerosus (Monogenea: Ancyrocephalinae) and its host, the Nile tilapia (Oreochromis niloticus), as bioindicators of chemical pollution. J Parasitol 2004; 93(5): 1097-1106. PMid:18163344. http://dx.doi. org/10.1645/GE-1162R.1

Soliman MFM, Ibrahim MM. Monogenean community structure of Oreochromis niloticus in relation to heavy metal pollution and host reproductive cycle. J Egypt Soc Parasitol 2012; 42(1): 11-24. PMid:22662591.

Takyama RT, Silva AQ, Costa WJP, Nascimento HS. Qualidade das águas das ressacas das bacias do Igarapé da Fortaleza e do Rio Curiaú. In Takyiama LR, Silva AC. Diagnóstico de ressacas do estado do Amapá: bacias do Igarapé da Fortaleza e do Rio Curiaú. Macapá: CPAQ/IEPADGEO/ SEMA; 2004. p. 81-104.

Tavares-Dias M, Martins ML, Moraes FR. Fauna parasitária de peixes oriundos de "pesque-pague" do município de Franca, São Paulo, Brasil. I. Protozoários. Rev Bras Zool 2001; 18(S1): 67-79. http://dx.doi. org/10.1590/S0101-81752001000500005

Van As JG, Basson L. Host specificity of trichodinid ectoparasites of freshwater fish. Parasitol Today 1987; 3(3): 88-90. http://dx.doi. org/10.1016/0169-4758(87)90166-9

Van As JG, Basson L. A further contribution to the taxonomy of the Trichodinidae (Ciliophora: Peritrichia) and a review of the taxonomic status of some fish ectoparasitic trichodinids. Syst Parasitol 1989; 14(3): 157-179. http://dx.doi.org/10.1007/BF02187051

Vulpe V. Parasitic invasions on fish stocks from the N-E area of Moldavia. Sci Parasitol 2002; 3(2):144-149. 